\title{
Sensitivity of Allium cepa and Vicia faba towards cadmium toxicity
}

\author{
S. K. Arya*, A. Mukherjee \\ Deparment of Botany, University of Calcutta, Kolkata-700019. India. *Corresponding author: shashiarya03@gmail.com
}

\begin{abstract}
Sensitivity of common onion (Allium cepa L.) and faba bean (Vicia faba L.) to cadmium (Cd) stress was investigated using genotoxicity endpoints. Simultaneously, the antioxidative stress enzymes (guaiacol peroxidise and catalase) and lipid peroxidation [malonaldehyde (MDA) content] were investigated in the plants exposed to Cd in solution. The endpoints screened for genotoxicity included chromosomal aberrations, micronuclei frequency and mitotic frequency. Additionally comet assay was performed for DNA fragmentation. Evan's blue uptake by the root meristems as a cell death parameter served as indicator of cytotoxicity. The results indicated that exposure to $\mathrm{Cd}$ induced dose-dependent increase in chromosomal aberrations, DNA fragmentation and micronucleus frequency in both A.cepa and $V$. faba. The enzymes guaiacol peroxidase (GPX) and catalase (CAT) activities increased in both the plants and were higher in $V$. faba. A positive correlation between the activity of GPX and CAT and MDA content was recorded at all concentrations of $\mathrm{Cd}$. Regarding sensitivity, our results showed that $V$. faba is more sensitive plant than A. cepa towards Cd -induced toxicity. Higher genotoxicity level correlated to the increased level of oxidative stress in root tissues. This was likely to be an important cause of Vicia plant to be less tolerant than Allium.
\end{abstract}

Keywords: Antioxidant enzymes, cadmium, chromosomal aberrations, comet assay, lipid peroxidation, micronucleus, mitotic frequency

\section{Introduction}

Vegetables are the staple food for most of the world and play an important role in human diet. Among these vegetables, onions are of great importance and a natural part of the daily diet for most of the world's population. Common red onion (Allium cepa L.) is a vegetable of great economic importance grown all over the world (Mogren et al., 2007). In recent years, the consumption of faba beans - Vicia faba L. has increased, as they are rich source of protein, vitamin and minerals (Duc, 1997). Although V. faba are consumed less in western countries, it is one of the main source of protein and energy in Africa, Asia and Latin America.

The heavy metals like cadmium (Cd) and other pollutants in agricultural soils have led to bioaccumulation of various toxicants in food crops; (Nagajyoti et al., 2010) 
that are easily absorbed by soil and accumulated in different plant parts such as root, stem and leaf. $\mathrm{Cd}$ induces clastogenic and genotoxic disturbance in plants and inhibits root growth and cell division in different plants ( Fojtova and Kovarik, 2000). Available reports confirm that $\mathrm{Cd}$ induces oxidative burst via the generation of reactive oxygen species (ROS), such as $\mathrm{H}_{2} \mathrm{O}_{2}, \mathrm{O}_{2}$-- radicals, and. $\mathrm{OH}$ radicals as well as disturbance to antioxidative systems (Romero-Puertas et al., 2004). The Cd-induced genotoxicity events have been reported in Vicia (Unyayar et al., 2006; Zhang et al., 2009) and Allium species (Unyayar et al., 2006). The karyological characteristics i.e. low number and long chromosomes, make the observations of nucleus damage substantially easy. The International Program on Chemical Safety (IPCS) and the World Health Organization (WHO) (Ma, 1999) prefer $V$. faba and A. cepa seedlings for screening and monitoring of genotoxic agents and mitotic studies (Gopalan, 1999).

The aim of the present work was to determine the sensitivity of the two plants $V$. faba and A. cepa towards $\mathrm{Cd}$ - induced genotoxicity. Chromosomal aberrations, micronucleus formation and DNA breaks are regarded as the indicators of genotoxicity. Since oxidative stress is implicated in the production of such damages, we have carried experiments to compare the sensitivity of Allium and Vicia performed at the same time and under same conditions. Additionally, antioxidant enzyme activities and cytotoxic effects of $\mathrm{Cd}$ were assessed.

\section{Materials and Methods}

\subsection{Chemicals}

Cadmium chloride (CAS No 35658-65-2), N, $\mathrm{N}$-dimethylformamide, hydrogen peroxide $\left(\mathrm{H}_{2} \mathrm{O}_{2}\right)$, glacial acetic acid, mercuric chloride, disodium EDTA, sodium chloride $(\mathrm{NaCl})$, sodium hydroxide $(\mathrm{NaOH})$, trizma base and hydrochloric acid $(\mathrm{HCl})$ was purchased from Merck India Ltd, Mumbai, India. Evan's blue, thiobarbituric acid, trichloroacetic acid, ethanol, magnesium chloride $\left(\mathrm{MgCl}_{2}\right)$, polyvinyl pyrrolidone (PVP) and orcein was purchased from Himedia, India Ltd. Ethyl methane sulphonate (EMS), ethidium bromide and low melting point agarose (LMPA) were purchased from Sigma-Aldrich Co. (USA). Guaiacol was purchased from SRL, Mumbai, India.

\subsection{Plant materials and treatments}

Equal sized bulbs were chosen from a population of a local red variety of the common onion, Allium cepa L. $(2 \mathrm{n}=16)$. The onions were positioned for germination directly on autoclaved sand taken in earthen pots (Mukherjee and Gichner, 2009) at room temperature under a $12 \mathrm{~h} \mathrm{light/} \mathrm{dark} \mathrm{cycle.} \mathrm{Seeds} \mathrm{of} V$. faba purchased from Institute of Agriculture Sciences, Banaras Hindu University, Varanasi, India were sterilized in $0.1 \%(\mathrm{w} / \mathrm{v}) \mathrm{HgCl}_{2}$ for $8 \mathrm{~min}$. The seeds were washed with tap water and soaked for $18 \mathrm{~h}$ in dark. Seeds were allowed to germinate on moistened filter paper at $25{ }^{\circ} \mathrm{C}$ for $4-5$ days in petriplates. To get a luxuriant biomass of secondary roots, excised primary root tips of $V$ faba were transferred to plastic vials containing tap water. To ensure equivalent available $\mathrm{Cd}$ uptake by the roots, root biomass taken for Cd- treatment at similar concentration in A.cepa and $V$. faba was same. Roots of both plants were immersed in plastic vials containing $30 \mathrm{ml}$ of a defined concentration of $\mathrm{CdCl}_{2}(50,100,200 \mu \mathrm{M})$ and EMS (2 $\mathrm{mM}$ ) dissolved in distilled water for $2 \mathrm{~h}$ in the dark at $22{ }^{\circ} \mathrm{C}$. Negative (distilled water) control was included in the experiment. After a recovery period of $24 \mathrm{~h}$, the roots of $A$. cepa and $V$. faba were used for comet assay and other tests as applicable.

\subsection{Analysis of Cadmium}

Atomic absorption spectrophotometer was used to analyse the Cd content in root tissue of $A$. cepa and $V$. faba. After treatment root tissues were oven dried, ground and digested with concentrated $\mathrm{HNO}_{3}: \mathrm{HClO}_{4}$ (1:3). Digested samples were filtered and diluted with redistilled water to $25 \mathrm{ml}$. Cd concentrations were determined according to the standard method 
of the American Public Health Association (1998) using atomic absorption spectrometry (AAS4136A, Electronic Corporation of India Limited, Hyderabad, India). Acid matrix blanks were included to assess possible Cd contamination.

\subsection{Cell death measurement and visualization}

To detect cytotoxicity intact roots (length $\sim 2 \mathrm{~cm}$ ) of control and treated samples were stained in aqueous solution of Evan's Blue [0.25\% (w/v)] for $30 \mathrm{~min}$ (Baker and Mock, 1994). Five stained root tips were transferred to $1 \mathrm{ml}$ of $\mathrm{N}, \mathrm{N}$-dimethylformamide for $1 \mathrm{~h}$ at room temperature. The absorbance of Evan's blue was measured at $600 \mathrm{~nm}$ (Beckman Coulter DU730 Lifescience UV/ Vis spectrophotometer).

\subsection{Extraction and estimation of antioxidative enzymes and MDA content}

$300 \mathrm{mg}$ of fresh root tissues of control and treated samples were homogenized in $900 \mu \mathrm{L}$ extraction buffer $[50 \mathrm{mM}$ Tris- $\mathrm{HCl}$ pH 7.8 containing $1 \mathrm{M}$ EDTA, $1 \mathrm{mM} \mathrm{MgCl} 2, \quad 1.5 \%$ PVP (w/v)]. The homogenates were centrifuged at $15000 \mathrm{rpm}$ for 20 $\min$ at $4{ }^{\circ} \mathrm{C}$. The supernatants were collected and kept at $-20^{\circ} \mathrm{C}$ for further use to analyze the GPX and CAT activities (Meng et al., 2007). The protein content in the enzyme extracts was estimated according to the method of Lowry et al. (1951) using BSA as a standard.

Catalase (CAT) activity was determined following the method of Aebi (1974) with some modifications. The assay mixture in total volume of $1.5 \mathrm{ml}$ contained $1 \mathrm{ml}$ of $100 \mathrm{mM}$ potassium phosphate buffer $(\mathrm{pH} 7)$, $0.4 \mathrm{ml} 200 \mathrm{mM} \mathrm{H}_{2} \mathrm{O}_{2}$ and $0.1 \mathrm{ml}$ enzyme extract. The decrease in absorbance was measured at 240 $\mathrm{nm}\left(\varepsilon=0.036 \mathrm{mM}^{-1} \mathrm{~cm}^{-1}\right)$ spectrophotometrically (Beckman Coulter DU730 Lifescience UV/ Vis spectrophotometer). Enzyme activity was expressed as unit $\mathrm{min}^{-1} \mathrm{mg}^{-1}$ protein.
Guaiacol peroxidase (GPX) activity was assayed according to the method of Hemeda and Klein (1990). $6 \mathrm{ml}$ of reaction mixture contained $1 \mathrm{ml}$ of $1 \%$ guaiacol $(\mathrm{v} / \mathrm{v}), 1 \mathrm{ml}$ of $1 \% \mathrm{H}_{2} \mathrm{O}_{2}(\mathrm{v} / \mathrm{v})$ and $4 \mathrm{ml}$ of $50 \mathrm{mM}$ potassium phosphate buffer ( $\mathrm{pH}$ 6.1). $10 \mu \mathrm{l}$ enzyme extract was added to reaction mixture. The increase in absorbance due to oxidation of guaiacol $\left(\varepsilon=26.6 \mathrm{mM}^{-1} \mathrm{~cm}^{-1}\right)$ at $470 \mathrm{~nm}$ was monitored in Beckman Coulter DU730 Lifescience UV/ Vis spectrophotometer. Enzyme activity was expressed as unit $\mathrm{min}^{-1} \mathrm{mg}^{-1}$ protein.

Extent of lipid peroxidation in terms of MDA formation was determined in roots of control and treated plants following the method of Karabal et al. (2003) with few modifications. $0.2 \mathrm{~g}$ fresh root tissues of control and treated samples were homogenized in $1 \mathrm{ml}$ of $5 \%(\mathrm{w} / \mathrm{v})$ trichloroacetic acid (TCA) in an ice bath. Homogenates were centrifuged at $12000 \mathrm{rpm}$ for $15 \mathrm{~min}$ at room temperature. $100-\mu 1$ supernatant was added to equal volume of $0.5 \%(\mathrm{w} / \mathrm{v})$ thiobarbituric acid (TBA) in $20 \%(\mathrm{w} / \mathrm{v})$ TCA. The mixtures were heated at $95{ }^{\circ} \mathrm{C}$ for $25 \mathrm{~min}$ and cooled immediately. Subsequently, the mixtures were centrifuged at 10000 rpm for $5 \mathrm{~min}$ and absorbance of the supernatant was measured at $532 \mathrm{~nm}$. MDA content $\left(\varepsilon=1.56 \times 10^{5}\right.$ $\mathrm{M}^{-1} \mathrm{~cm}^{-1}$ ) was calculated and expressed in $\mu \mathrm{M} / \mathrm{g}$ of fresh weight.

\subsection{Genotoxicity assay}

For genotoxicity, the following endpoints- mitotic index (MI), chromosomal aberrations (CAs) and micronuclei (MN) were assessed in A. cepa and $V$. faba root tip cells. Root tips $(1 \mathrm{~cm})$ from control and treated samples were excised and fixed immediately in Carnoy's fluid (ethanol: glacial acetic acid 3:1). Root tips were hydrolyzed and stained in warm $2 \%$ acetoorcein stain (aceto-orcein: $1 \mathrm{~N} \mathrm{HCl} \mathrm{9:1)} \mathrm{and} \mathrm{squashed}$ in $45 \%$ acetic acid. Slides were prepared and coded following the method of Mukherjee and Sharma (1988). Approximately 3000 cells per concentration were scored under a binocular light microscope (Japan, Olympus BX51) at 40X magnification. 
MI was determined by counting the number of mitotic cells among the total amount of scored cells per treatment (including control). Mean values for each endpoint were calculated and statistically correlated. The methods of Navarrete et al. (1997), Mukherjee and Gichner (2009) were followed to detect DNA damage in the roots of A. cepa and $V$. faba. Roots of control and treated samples were harvested, washed and blotted dry. All the procedures were performed under dim light and in cooling condition. Nuclei were isolated by chopping the roots with fresh blade in 60 $\mathrm{mm}$ petriplates containing $400 \mu \mathrm{l}$ of $400 \mathrm{mM}$ Tris buffer ( $\mathrm{pH}$ 7.4). The slides were prepared as described by Navarrete et al. (1997) and placed in a horizontal gel tank (Life Technologies, California, USA) containing alkaline electrophoresis buffer $(300 \mathrm{mM} \mathrm{NaOH}$ and 1 mM EDTA; $\mathrm{pH}>13$ ) for $20 \mathrm{~min}$ at $40{ }^{\circ} \mathrm{C}$. This was followed by electrophoresis at $26 \mathrm{~V}$ and $300 \mathrm{~mA}$ current for $20 \min (A$. cepa) and $15 \min (V . f a b a)$. Slides were neutralized in $400 \mathrm{mM}$ Tris $\mathrm{pH} 7.4$ for $5 \mathrm{~min}$ and finally washed in water. Subsequently, the slides were stained with $\operatorname{EtBr}(20 \mu \mathrm{g} / \mathrm{ml})$ and rinsed in water. Stained slides were scored ( $25 \times 3$ per sample) and photographed (100X) using image analysis system (Kinetic imaging; Andor Technology, Nottingham, UK) attached to a fluorescence microscope (Leica, Wetzlar, Germany). Images were analysed by Komet 5.5 software.

\subsection{Statistical analyses}

Sigma Stats.3 software (SPSS Inc., Chicago, Illinois, USA) was used for all statistical analysis using oneway ANOVA test and the level of significance was established at 0.05 .

\section{Results}

\subsection{Cd content estimation}

$\mathrm{Cd}$ analysis in root tissues of A.cepa and $V . f a b a$ is presented in Table 1. Cd content detected correlated with the $\mathrm{Cd}$ concentration in solution and expressed, as $\mu \mathrm{g} \mathrm{g}^{-1} \mathrm{DW}$ (dry weight). In control set, Cd content was below detectable level in both the plants.

\subsection{Measurement of cell death}

$\mathrm{CdCl}_{2}$ exposure induced cell death in root cells of both A. cepa and $V$. faba (Figure 1). A $\sim 2$ - 3.5 fold increase in Evan's blue uptake was observed in $A$. cepa and $V$. faba, indicating cytotoxic effect of $\mathrm{Cd}$ on plants.

\subsection{Examination of antioxidant enzyme activities and MDA concentration}

Figure 2A shows GPX activities in the roots of $A$. cepa and $V . f a b a$, exposed to different concentrations of $\mathrm{Cd}$. GPX activity was highest (92.81 $\mathrm{U} \mathrm{min}^{-1} \mathrm{mg}^{-1}$ protein) at $100 \mu \mathrm{M}$ of $\mathrm{Cd}$ in A. cepa; whereas in V. faba, the highest activity (179.13 $\mathrm{U} \mathrm{min}^{-1} \mathrm{mg}^{-1}$ protein) was at $200 \mu \mathrm{M}$.

Information on CAT activity is given in Figure 2B. In V. faba increase in CAT activity was significantly ( $p \leq$ 0.05 ) higher over control and other treatment groups. The values were $\sim 29$ fold higher than control. In $A$ cepa, the values of CAT activity increased from 32.63 $\mathrm{U} \mathrm{min}{ }^{-1} \mathrm{mg}^{-1}$ protein in control to a value of $167.00 \mathrm{U}$ $\mathrm{min}^{-1} \mathrm{mg}^{-1}$ protein at highest $\mathrm{Cd}$ concentration.

The effects of $\mathrm{Cd}$ on MDA concentration are presented in Figure 3. Lipid peroxidation expressed in terms of MDA formed in root tissues of A. cepa and $V$. faba increased significantly $(p \leq 0.05)$ with increasing concentration of Cd. The MDA contents in $V$. faba were significantly $(p \leq 0.05)$ higher at all concentrations over the treatment groups in A. cepa.

\subsection{Genotoxicity assay}

Mitotic index and micronuclei frequency in $A$. cepa and $V . f a b a$ are presented in Figure 4. With increasing $\mathrm{Cd}$ concentration, the mitotic index decreased significantly $(p \leq 0.05)$ whereas the frequency of cells with MN increased in both $A$. cepa and $V$. faba. A similar trend was noted in the plants exposed to the positive control EMS (2mM). 
Table1. Cd content in roots of $A$. cepa and $V$. faba treated with cadmium chloride (0, 50, 100 and $200 \mu \mathrm{M})$. Each value is the mean of three individual samples $\pm \mathrm{SD}$; *Significant compared to control at $p \leq 0.05$.

\begin{tabular}{|c|c|c|}
\hline $\begin{array}{l}\text { Concentration of } \mathrm{CdCl} 2 \\
(\mu \mathrm{M})\end{array}$ & $\begin{array}{c}\text { Cd content in A. cepa roots } \\
\text { ( } \mu g g-1 D W)\end{array}$ & $\begin{array}{c}\text { Cd content in } V \text {. faba roots } \\
\text { ( } \mu g g-1 D W)\end{array}$ \\
\hline $\mathbf{0}$ & BDL & BDL \\
\hline 50 & $0.052 \pm 0.02^{*}$ & $0.102 \pm 0.02^{*}$ \\
\hline 100 & $0.098+0.01^{*}$ & $0.153+0.02^{*}$ \\
\hline 200 & $0.139+0.01 *$ & $0.192+0.02^{*}$ \\
\hline
\end{tabular}

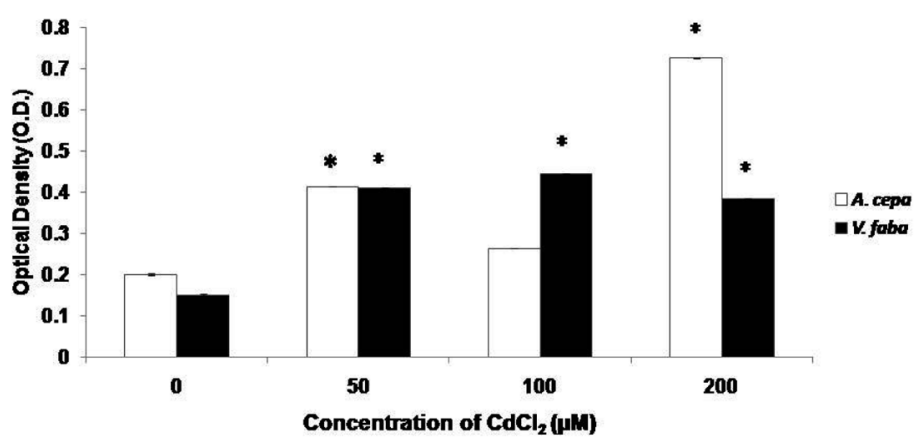

Figure 1. Bar graph showing release of Evan's blue into N, N- dimethyl formamide solution representing induction of cell death induced by cadmium chloride in Allium cepa and Vicia faba root tissues, using Evan's blue stain; Each value is the mean of three individual samples $\pm \mathrm{SD}$; *Significant compared to control at $p \leq 0.05$.

The inhibition of cell division was more pronounced in A. cepa than that in $V$. faba roots. In A. cepa compared to control, at the highest concentration $(200 \mu \mathrm{M})$ there was a $\sim 61 \%$ reduction in divisional frequency and $\sim 42 \%$ reduction in $V$. faba. Such mitotic inhibition reflects toxic effect of the test compound. The number of cells with $\mathrm{MN}$ was more or less similar to that observed in $V$. faba and $A$. cepa. The values ranged between $9.7-10.4 \%$ in $A$. cepa and $7.54-10.78 \%$ in $V$. faba was found at varying concentration of $\mathrm{Cd}$.
Concomitant to MN formation, the chromosomal aberrations were also observed in the root meristematic cells. Figure 5 represents the chromosomal aberrations recorded at different mitotic stages e.g. anaphase- telophase bridges, chromosome laggards and chromosome breaks. Figure 6 represents total aberrations of A. cepa and V. faba root cells. Compared to control, a total chromosomal aberration recorded at the highest concentration of Cd was $14.24 \%$ in $A$. cepa and $23.27 \%$ in $V$. faba. 

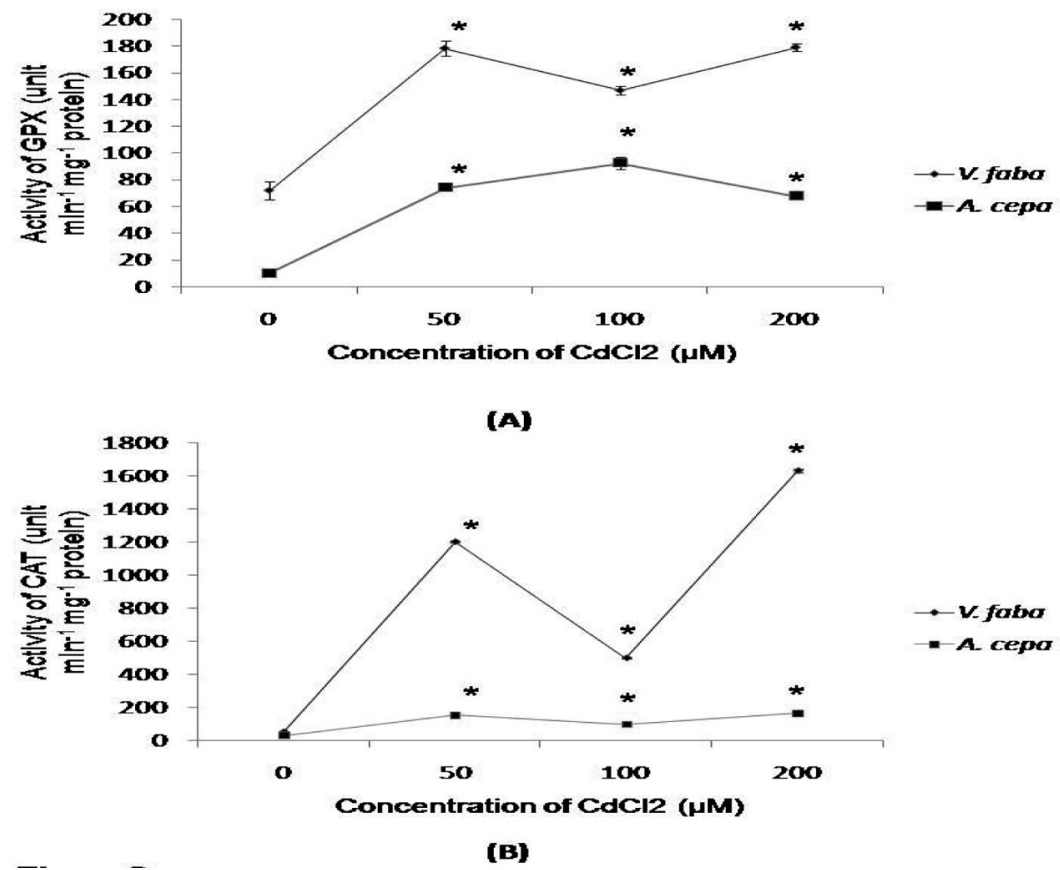

Figure 2. (A) Activity (unit $\mathrm{min}^{-1} \mathrm{mg}^{-1}$ protein) of Guaiacol peroxidase in roots of $A$. cepa and $V$. faba treated with cadmium chloride; *Significant at $p \leq 0.05$. (B) Activity (unit $\mathrm{min}^{-1} \mathrm{mg}^{-1}$ protein) of catalase in roots of $A$. cepa and $V$. faba treated with cadmium chloride; *Significant at $p \leq 0.05$.

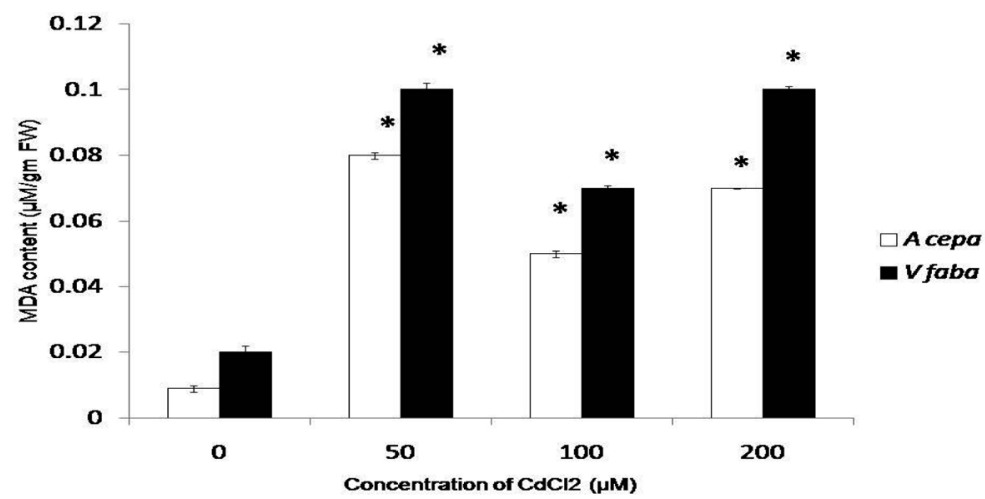

Figure 3. MDA content in root tissues of $A$. cepa and $V$. faba treated with cadmium chloride. Each value is the mean of three individual samples $\pm \mathrm{SD} ;{ }^{*}$ Significant at $p \leq 0.05$. 

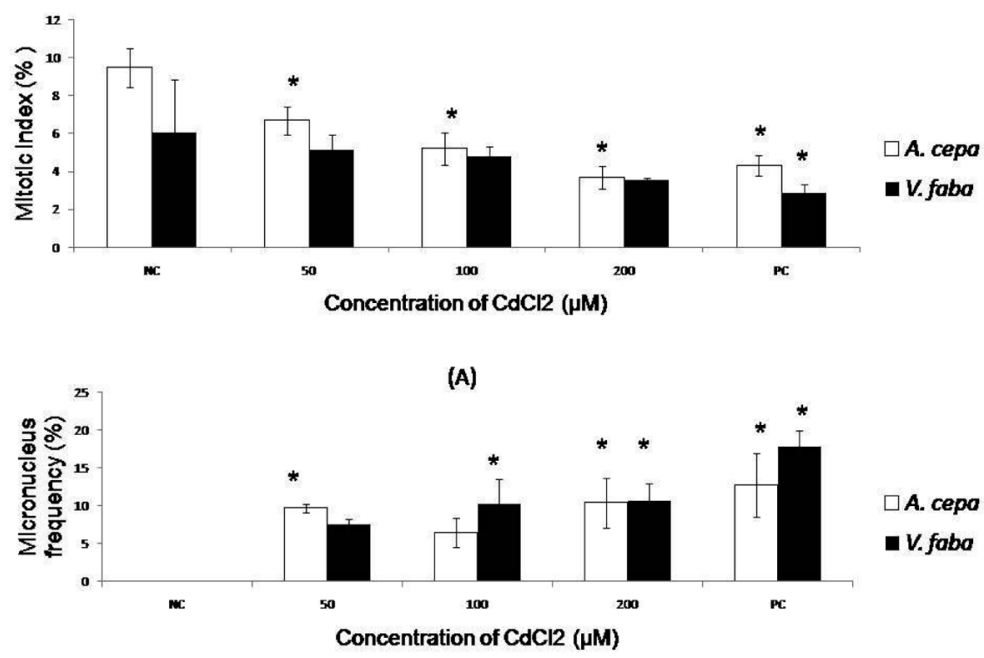

(B)

Figure 4. Mitotic index (A) and micronucleus frequency (B) values in A. cepa and V. faba root tips exposed to cadmium chloride. Values are mean of three samples. The symbol $(*)$ among treatments indicate significant differences at $p \leq 0.05$ [NC, negative control; PC, positive control (2mM EMS)].

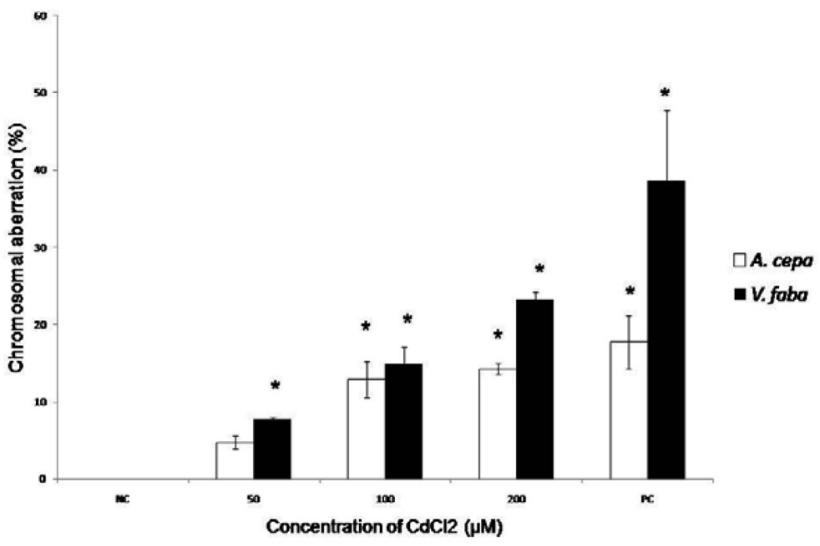

Figure 5. Chromosomal aberrations in root tip cells of $A$. cepa and $V$. faba. Data are presented as the mean $\pm \operatorname{SD}$ (n $=3) ;{ }^{*}$ Significant at $p \leq 0.05$; NC- negative control, PC- positive control (2mM EMS). 


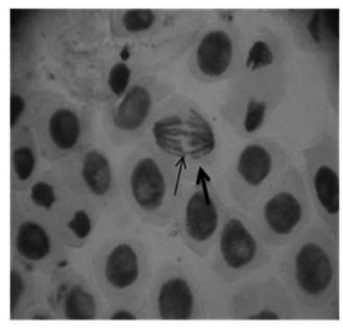

A

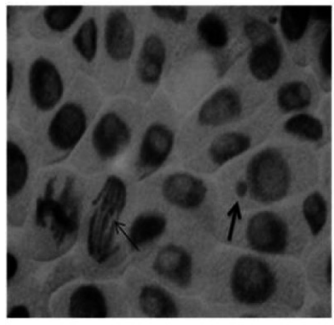

C

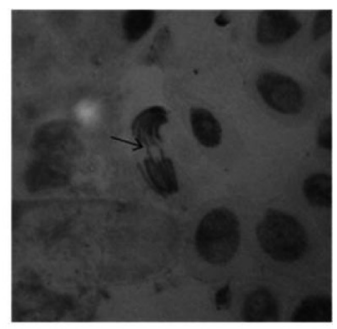

B

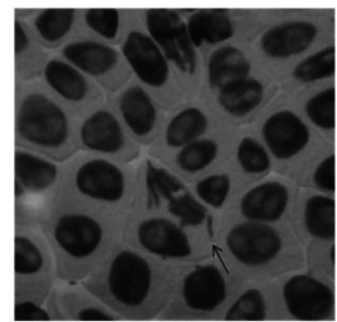

D

Figure 6. Photomicrographs showing chromosomal aberration in root tip cells of $A$. cepa and $V$. faba treated with cadmium chloride (Magnification= 400X) (A) Chromosomal break ( $\uparrow$ ) and bridge ( $\uparrow)$ (B) Chromosome bridge $(\uparrow)$ (C) Micronucleus $(\uparrow)$ and bridge $(\uparrow)$ (D) Chromosomal laggard $(\uparrow)$

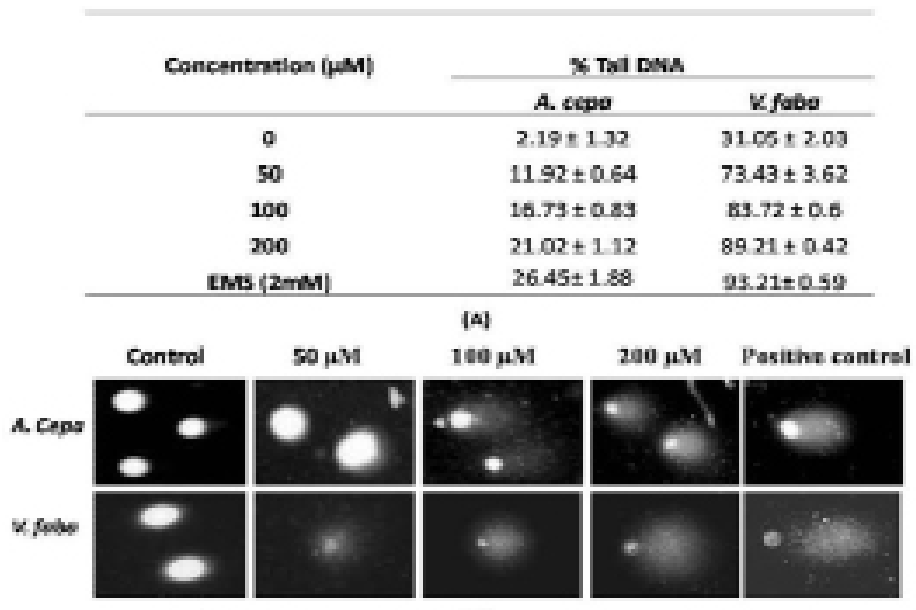

(B)]

Figure7. (A) Comet parameter \% tail DNA indicating of extent of DNA fragmentation induced by cadmium chloride in root nuclei of A. cepa and V. faba; (B) Representative images of damaged nuclei (100X) in A. cepa and V. faba roots induced by cadmium chloride 
The chromosomal aberrations recorded in the positive control EMS (2mM) were 17.75 and $38.58 \%$ in A. cepa and V. faba respectively. Concerning the genotoxicity parameters (MI, micronuclei frequency and CA), it was found that $V$. faba was more sensitive than A. cepa when exposed to EMS and to $\mathrm{CdCl}_{2}$.

The DNA migrations (comet assay) in root meristematic samples are shown in Figure 7. In both the plants, the values of tail DNA percent increased significantly $(p \leq 0.05)$ in a dose- dependent manner and was comparable to that induced by EMS ( $2 \mathrm{mM})$. The control values of DNA damage as measured by percent tail DNA was considerably high in $V$. faba $(31.05 \%)$ than that in A. cepa $(2.19 \%)$. Since the comet assay was performed under same conditions, it is possible to conclude that $V$. faba is more sensitive to the $\mathrm{CdCl}_{2}$ exposure than A. cepa.

\section{Discussion}

The primary objective of this study was to assess the sensitivity of different endpoints measured in $V$. faba and A. cepa plants exposed to $\mathrm{CdCl}_{2}$ in solution. The research aimed to determine whether, through measuring different endpoints simultaneously in the same protocol (cytotoxicity, MDA content, activity of antioxidative enzymes- guaiacol peroxidase and catalase, chromosomal aberrations, micronuclei formation and DNA damage) it is possible to demonstrate that changes detected can be associated with the sensitivity of the plants.

The decrease in cell division and the increase in Evan's blue uptake observed in the root cells of both $A$. cepa and $V$. faba indicate the cytotoxicity of $\mathrm{CdCl}_{2}$ on the plants. The chromosomal aberrations, micronuclei frequency and DNA breaks demonstrate that $\mathrm{Cd}$ had a genotoxic effect. Considering the endpoints performed $V$. faba appeared to be more sensitive than $A$. cepa when exposed to $\mathrm{Cd}$ in solution. The total chromosomal aberrations, micronuclei frequency and
DNA migration (\% tail DNA) recorded were of higher values in Vicia. The antioxidant enzyme activities GPX, CAT and lipid peroxidation expressed in terms of MDA formed were higher in Vicia than in Allium. Sensitivity to $\mathrm{Cd}$ toxicity has been reported among different plant species (Unyayar et al., 2006). $\mathrm{CdCl}_{2}$ is known to be highly available for plant and to induce micronucleus in $V$. faba and A. cepa (Seth et al., 2008). Seth et al. (2008) suggested that exposure to $\mathrm{Cd}$ prevented cells entering cell division phases, which then resulted in a decrease in MI. Additionally, the primary action of $\mathrm{Cd}$ on the mitotic spindle promoted spindle-related abnormalities such as laggard chromosomes and bridges during cell division, which has been reported in our findings. The mitotic depression caused by heavy metals is found to prevent a number of cells entering the prophase thereby blocking the mitotic phase of the cell cycle.

The molecular mechanism responsible for the genotoxicity of $\mathrm{Cd}$ remains largely unclear, it may involve either direct or indirect interaction of $\mathrm{Cd}$ with DNA (Valverde et al., 2001). In Vicia / tobacco the $\mathrm{Cd}$, induced DNA damage observed in the acellular comet assay after treatment of isolated nuclei without cytosol supports the assumption that the DNA damage induced by $\mathrm{Cd}$ is preferentially mediated indirectly (Gichner et al., 2004). Apparently, the metabolic products of $\mathrm{Cd}$ induced stress in the cytosol i.e. ROS, mainly participate in the production of DNA damage, and the direct binding of $\mathrm{Cd}$ with nuclear DNA is of less importance. This metal depletes the cell's major antioxidants, particularly thiol-containing antioxidants and enzymes and thus may cause an increase in production of ROS such as the hydroxyl radical, the superoxide radical or hydrogen peroxide. Enhanced generation of ROS can overwhelm the cell's intrinsic antioxidant defences, and result in a condition known as "oxidative stress". Cells under oxidative stress display various dysfunctions due to lesions caused by ROS to lipids, proteins and DNA (Romero-Puertas et al., 2004). This is in disagreement with the report of Hossain and Huq (2002) according to them Cd 
may directly bind with DNA possibly at G, A and $\mathrm{T}$ bases. Cd toxicity enhances lipid peroxidation in plant cells, reflected by increased MDA concentration (Chaoui et al., 1997). This suggests that Cd indirectly leads to production of superoxide radicals, resulting in increased lipid peroxidative products and high oxidative stress in $V$. faba than A. cepa. Lipid peroxidation induced by $\mathrm{Cd}$ may be due to the attack of free radicals on the fatty acid component of membrane lipids. Excessive generation of MDA may be responsible for the higher DNA damage in the treated root cells. This was observed in our study. The enhanced level of lipid peroxidation is one of the major indicators of $\mathrm{Cd}$ induced oxidative stress (Chaoui et al., 1997). Cell death or the senescence as evaluated by Evan's blue test is also high in $V$. faba plants (Figure 1). This could be attributed to the induction of high MDA content or lipid peroxidation suggestive of high production of ROS leading to cell death in $V$. faba making it more sensitive towards $\mathrm{Cd}$. Moreover, the loss of membrane integrity, a primary marker of loss of cell viability is in accordance with the observed peroxidation of lipids and is consistent with the increase of cell senescence and death, because of higher exposure to $\mathrm{Cd}$. In the present study, $\mathrm{Cd}$ induced lipid peroxidation, resulted in ROS formation. In reponse to a defensive mechanism, antioxidative enzymes, GPX and CAT were induced correspondingly for removing free radicals and scavenging ROS. The significant responses of GPX and CAT activities in $A$. cepa and $V$. faba suggested antioxidative enzymatic system might play an important role in the resistance of plant to Cd stress. Several researchers reported that the increase of antioxidant enzyme activities in response to $\mathrm{Cd}$ and other heavy metal exposure might be taken as evidence for an enhanced detoxification capacity of $V$. faba (Cordova Rosa et al., 2003), A. cepa (Fatima and Ahmad, 2005) and Allium sativum (Xu et al., 2008) plants towards ROS that might be generated in stress conditions. It has already been reported that A. cepa contains phenol compounds, particularly flavonols like Quercetin-4' glucoside, Quercetin-3, 4' diglucoside etc. which are potential free radical scavenger that might aid tolerance to this plant (Caridi et al., 2007; Prakash et al., 2007). The results in the present study are in accordance with the earlier reports with characteristic differences in $\mathrm{Cd}$ accumulation when comparing one vegetable to another, following the order: legumes (Leguminosae) $<$ melon vegetables (Cucurbitaceae) $<$ alliums (Amaryllidaceae and Liliaceae) $<$ root vegetables (Umbelliferae and Cruciferae) $<$ kail vegetables (Cruciferae) $<$ solanaceous vegetables (Solanaceae) $<$ leafy vegetables (Cruciferae, Compositae and Chenopodiaceae). As the plant $V$. faba belongs to Fabaceae or Leguminosae, its place in relation to $\mathrm{Cd}$ tolerance comes last.

\section{Conclusion}

This study accommodated the detailed cytotoxic and genotoxic effects of $\mathrm{Cd}$ in higher plants that are also important vegetables. Based on the results of the present study we can conclude that Vicia is more sensitive to $\mathrm{Cd}$ exposure and caution should be exercised while growing this plant on Cd-contaminated sites. Considering the myriad of endpoints screened, $V$. faba was found to be more sensitive than A. cepa. Additional studies on the molecular mechanism that confers such sensitivity should be conducted.

\section{Acknowledgements}

The authors are thankful to UGC [F.4-2/2006 (BSR)/ 13- 445/ 2011 (BSR), dt 12/9/2011] for the financial support.

\section{Reference}

Aebi, H. 1974. Catalase; Methods in enzymatic analysis. In: H.U. Bergmeyer (eds), Academic press, New York, pp 673-684. 
American Public Health Association (APHA). 1998. Standard Methods for the Examina- tion of Water and Wastewater, 20th ed. Washington, DC.

Baker, C.J., Mock, N.M. 1994. An improved method for monitoring cell death in cell suspension and leaf disc assays using Evan's blue. Plant Cell Tissu. Org. Cult. 39, 7-12.

Caridi, D., Trenerry, V.C., Rochfort, S., Duong, S., Laugher, D., Jones, R. 2007. Profiling and quantifying quercetin glucosides in onion (Allium cepa L.) varieties using capillary zone electrophoresis and high performance liquid chromatography. Food Chem. 105, 691-699.

Chaoui, A., Mazhoudi, S., Ghorbal, M.H., El Ferjani, E. 1997. Cadmium and zinc induction of lipid peroxidation and effects on antioxidant enzyme activities in bean (Phaseolus vulgaris L.). Plant Sci. 127,139-147.

Cordova Rosa, E.V., Valgas, C., Souza-Sierra, M.M., Correa, A.X.R., Radetski, C.M. 2003. Biomass growth, micronucleus induction, and antioxidant stress enzyme responses in Vicia faba exposed to cadmium in solution. Environ. Toxicol. Chem. 22, 645-649.

Duc, G. 1997. Faba bean (Vicia faba L.). Field Crops Res. 53, 99-109.

Fatima, R.A., Ahmad, M. 2005. Certain antioxidant enzymes of Allium cepa as biomarkers for the detection of toxic heavy metals in wastewater. Sci. Total Environ. 346, 256- 273.

Fojtova, M., Kovarik, A. 2000. Genotoxic effect of cadmium is associated with apoptotic changes in tobacco cells. Plant Cell Environ. 23, 531-537.

Gichner, T., Patkov'a, Z., Sz'akov'a, J., Demnerova, K. 2004. Cadmium induces DNA damage in tobacco roots, but no DNA damage, somatic mutations or homologous recombination in tobacco leaves. Mutat. Res. 559, 49-57.

Gopalan, H.N.B. 1999. Ecosystem health and human wellbeing: the mission of the International Program on Plant Bioassays. Mutat. Res. 426, 99-102.

Hemeda, H.M., Klein, B.P. 1990. Effects of naturally occurring antioxidants on peroxidase activity of vegetable extracts. J. Food Sci. 55,184-185.

Hossain, Z., Huq, F. 2002. Studies on the interaction between $\mathrm{Cd}^{2+}$ ions and DNA. J. Inorg. Biochem. 90, 85-96.

Karabal, E., Yucel, M., Oktem, H.A. 2003. Antioxidant responses of tolerant and sensitive barley cultivars to boron toxicity. Plant Sci. 164, 925-933.

Lowry, O.H., Rosebrough, N.J., Farr, A.L., Randall, R.J. 1951. Protein measurement with the Folin phenol reagent. J. Biol Chem. 193, 265-75.

Ma, T.H. 1999. The International Program on Plant Bioassays Collaborative Studies with Plant Systems. Mutat. Res. 426, 97-98.

Meng, Q., Zou, J., Zou, J., Jiang, W., Liu, D. 2007. Effect of $\mathrm{Cu}^{2+}$ concentration on growth, antioxidant enzyme activity and malondialdehyde content in garlic (Allium sativum L.). Acta Biol. Craco. Bot. 49, 95-101.

Mogren, L.M., Olssen, M.E., Gertsson, U.E. 2007. Effects of cultivar, lifting time and nitrogen fertiliser level on quercetin content in onion (Allium cepa L.) at lifting. J Sci. Food Agri. 87, 470-476.

Mukherjee, A., Gichner, T. 2009. Plant bioassays: comet assay in higher plants. In: D. A. Sampietro and S.S. Narwal (eds). Research Methods in Plant Sciences: Allelopathy. Studium Press, LLC. Houston,Texas, USA. pp: 97-108. 
Mukherjee, A., Sharma, A. 1988. Effects of cadmium and selenium on cell division and chromosomal aberrations in Allium sativum. Water Air Soil Poll. 37, 433-438.

Nagajyoti, P.C., Lee, K.D., Sreekanth, T.V.M. 2010. Heavy metals, occurrence and toxicity for plants. Environ. Chem. Lett. 8, 199-216.

Navarrete, M.H., Carrera, P., de Miguel, M., de la Torre, C. 1997. A fast comet assay variant for solid tissue cells. The assessment of DNA damage in higher plants. Mutat. Res. 389, 271-277.

Prakash, D., Singh, B.N., Upadhyay, G. 2007. Antioxidant and free radical scavenging activities of phenols from onion (Allium cepa). Food Chem. 102, 1389-1393.

Romero-Puertas, M., Rodriguez-Serrano, M., Corpas, F.J., Gomez, M., del Rio, L.A. 2004. Cadmium-induced subcellular accumulation of $\mathrm{O}^{2-}$ and $\mathrm{H}_{2} \mathrm{O}_{2}$ in pea leaves. Plant Cell Environ. 27, 1122-1134.

Seth, C.S., Misra, V., Chauhan, L.K.S., Singh, R.R. 2008. Genotoxicity of cadmium on root meristem cells of Allium cepa: cytogenetic and Comet assay approach. Ecotoxicol. Environ. Safety. 71, 711-716.
Unyayar, S., Celik, A., Cekic, F.O., Gozel, A. 2006. Cadmium-induced genotoxicity, cytotoxicity and lipid peroxidation in Allium sativum and Vicia faba. Mutagenesis. 21, 77-81.

Valverde, M., Trejo, C., Rojas, E. 2001. Is the capacity of lead acetate and cadmium chloride to induce genotoxic damage due to direct DNA-metal interaction?. Mutagenesis. 16, 265-270.

Xu, P., Zou, J., Meng, Q., Zou, J., Jiang, W., Liu, D. 2008. Effects of $\mathrm{Cd}^{+2}$ on seedling growth of garlic (Allium sativum L.) and selected physiological and biochemical characters. Bioresource Technol. 99, 6372-6378

Zhang, S., Zhang, H., Qin, R., Jiang, W., Liu, D. 2009. Cadmium induction of lipid peroxidation and effects on root tip cells and antioxidant enzyme activities in Vicia faba L. Ecotoxicol. 18, 814-823. 